\title{
UJI DAYA HAMBAT EKSTRAK BAWANG MERAH (Allium cepa L.) TERHADAP PERTUMBUHAN Salmonella typhi PADA MEDIA NUTRIENT AGAR (NA)
}

\author{
Widhorini ${ }^{1)}$, Ranti Rafianti ${ }^{2)}$ \\ ${ }^{1}$ Magister Pendidikan Biologi, Sekolah Pascasarjana Universitas Kuningan \\ Email: rinimrza@gmail.com \\ 2 FMIPA Universitas Al-Ghifari Bandung \\ Email: rantifathiya@gmail.com
}
APA Citation: Widhorini \& Rafianti, R. (2019). Uji Daya Hambat Ekstrak Bawang Merah (Allium cepa L.) Terhadap Pertumbuhan Salmonella typhi Pada Media Nutrient Agar (NA). Quagga: Jurnal Pendidikan dan Biologi, 11(2), 99-105. doi: 10.25134/quagga.v11i2.1877.

Received: 21-07-2019

Accepted: 29-07-2019

Published: 30-07-2019

\begin{abstract}
Abstrak: Salmonella termasuk dalam keluarga Enterobacteriace merupakan bakteri patogen bagi Manusia dan hewan. Infeksi Salmonella biasa menyerang saluran pencernaan dan tak jarang pula menyebar ke seluruh organ tubuh melalui peredaran darah. Tanaman obat yaitu macam-macam tanaman yang memiliki fungsi dan khasiat sebagai obat yang digunakan untuk menyembuhkan dan atau mencegah berbagai penyakit. Beberapa tanaman obat dilaporkan mempunyai kandungan anti oksidan dan aktivitas antibakteri, salah satunya yaitu bawang merah karena mengandung efek antiseptic dan senyawa alliin. Senyawa alliin akan diubah menjadi asam piruvat, ammonia, dan alliisin sebagai antimikroba yang bersifat bakterisida. Dengan demikian penelitian ini bertujuan untuk menentukan adanya aktivitas ekstrak Bawang Merah (Allium cepa L.) terhadap pertumbuhan Salmonella typhi No. ATCC 19430 pada media Nutrien Agar (NA). Ekstraksi dilakukan dengan cara maserasi menggunakan pelarut etanol 70\%.pengujian ini menggunakan konsentrasi 5\%, 10\%, 20\%, $30 \%, 40 \%$. Hasil penelitian menunjukkan nilai optimum pengujian ekstrak antibakteri pada bakteri Salmonella typhy No. ATCC 19430 terdapat pada konsentrasi 40\%, hal ini menunjukan semakin besar konsentrasi ekstrak tanaman uji berbanding lurus dengan besaran daya hambat terhadap bakteri Salmonella typhi No. ATCC 19430.
\end{abstract}

Kata kunci: Ekstrak Bawang Merah (Allium cepa L.), Salmonella typhy No. ATCC 19430, Antibakteri.

Abstract: Salmonella is included in family Enterobacteriace is pathogenic bacteria for humans and animals. Salmonella infections occur in channels cerna and sometimes spread via the blood circulation to the entire body. Medicinal plants are the kinds of plants that have a function and a nutritious and used as a medicine for healing or preventing various diseases. Many medicinal plants have reported deposits of anti oxidants and antibacterial activity. Shallots are classified as medicinal plants because it contains antiseptic effects and compounds alliin. Compounds alliin is converted into pyruvic acid, ammonia, and alliisin as antimicrobial that is bactericidal. The purpose of this research is to know the existence of the activity of the extracts of onion (Allium cepa L.) against the growth of Salmonella typhi No. ATCC 19430. on Nutrient Agar medium (NA). The extraction is done by means of maceration using solvent ethanol $96 \%$. This test using concentrations of 5\%, $10 \%, 20 \%, 30 \%, 40 \%$. The results showed the optimum value of antibacterial extract test on Salmonella typhi No. ATCC 19430 are present in a concentration of 40\%, this indicates the greater the concentration of the test plant extracts is directly proportional to the magnitude of drag against the power of the bacteria Salmonella typhi No. ATCC 19430.

Keywords: Extract of onion (Allium cepa L.), Salmonella typhy No. ATCC 19430, antibacterial.

\section{PENDAHULUAN}

Bakteri Salmonella sp. merupakan mikroba pathogen penyebab sakit perut yang dapat mengakibatkan kematian, yang disebut sebagai Salmonellosis. Usus manusia dan hewan merupakan habitat alami Salmonella sp., sedangkan air dan makanan sebagai media perantara penyebaran Salmonella sp. (Cliver, 1990). Salmonella sp. akan menginfeksi manusia melalui makanan yang sudah tercemar bakteri Salmonella sp. yang kemudian makanan tersebut dikonsumsi oleh manusia.

Bakteri Salmonella termasuk dalam famili Enterobacteriace merupakan bakteri patogen bagi manusia dan hewan. Infeksi Salmonella terjadi pada saluran cerna dan terkadang menyebar lewat peredaran darah ke seluruh organ tubuh (Lud W,2004). 
Tanaman obat adalah jenis-jenis tanaman yang memiliki fungsi dan berkhasiat sebagai obat dan dipergunakan untuk pencegahan maupun penyembuhan berbagai penyakit. Tanaman berkhasiat obat berarti tanaman tersebut mengandung zat aktif yang dapat mengobati suatu penyakit atau dapat juga tidak memiliki kandungan zat aktif tertentu tapi memiliki kandungan efek resultan / sinergi dari berbagai zat yang mempunyai efek mengobati.

Banyak tanaman obat yang dilaporkan mempunyai kandungan anti oksidan dan aktivitas antibakteri. Bawang merah mengandung beberapa senyawa penting bagi tubuh diantaranya vitamin $C$, kalium, serat, asam folat, kalsium dan zat besi. Selain itu bawang merah juga mengandung zat pengatur tubuh alami berupa hormone auxin dan giberelin. Bawang merah dikelompokan kedalam tanaman obat karena memiliki kandungan efek antiseptic dan senyawa alliin. Senyawa alliin akan diubah menjadi asam piruvat, ammonia, dan alliisin sebagai antimikroba yang bersifat bakterisida, dimana enzim yang berperan dalam mengubah senyawa alliin ini yaitu enzimallinase .(Stecher P.G, 1968).

Aliin (S-Allil-L-sistein sulfoksida), $\mathrm{C}_{6} \mathrm{H}_{11} \mathrm{NO}_{2} \mathrm{~S}$ tidak hanya terdapat dalam bawang merah, pada bawang putih (Allium sativum L.) dan jenis-jenis Allium lainnya juga terkandung senyawa ini. Senyawa aliin berupa hemihidrat yang tidak berwarna $\mathrm{C}_{6} \mathrm{H}_{11} \mathrm{NO}_{2} \mathrm{~S}$. ${ }^{1 / 2} \mathrm{H}_{2} \mathrm{O}$ berbentuk jarum tumpul yang didapat dari hasil rekristalisasi menggunakan pelarut aseton. Jarak leburnya $164-166^{\circ} \mathrm{C}$ (dengan mengeluarkan gas), mudah larut dalam air. Tidak larut dalam etanol mutlak, kloroform, aseton, eter, dan benzena. Senyawa ini berpotensi sebagai antibakteri dan mudah terurai oleh pengaruh enzim allinase dengan mengeluarkan bau bawang yang khas. Potensi antibakterinya hampir serupa dengan allicin.(Stecher P.G, 1968).

Menurut penelitian yang dilakukan oleh KG Wiryawan, (2005) mengenai anti bakteri dari Temulawak, Jahe, dan Bawang Putih Terhadap Salmonella typhi, menunjukkan adanya aktivitas anti bakteri oleh bawang putih terhadap S.typhi. Oleh karena itu penulis ingin melakukan penelitian tentang uji aktivitas eksrak bawang merah terhadap Salmonella typhi, melihat bahwa kandungan pada bawang merah dan bawang putih yang hampir serupa.

Berdasarkan uraian diatas, penelitian ini bertujuan untuk menentukan aktivitas ekstrak bawang merah terhadap pertumbuhan Salmonella typhi No. ATCC 19430 secara in vitro.

\section{METODOLOGI PENELITIAN Alat dan Bahan}

Alat yang digunakan dalam penelitian ini adalah pisau stainless steel, botol vial, $\mathrm{pH}$ meter, tabung sentrifugasi, pipet volume, kuvet,mikro pipet, inkubator (Enaco) kertas wattman no 52, kaca arloji, gelas kimia $50 \mathrm{ml}$ (Pyrex), gelas kimia $100 \mathrm{ml}$ (Pyrek), gelas kimia $250 \mathrm{ml}$ (Pyrex), gelas kimia $1000 \mathrm{ml}$ (Pyrex), cawan penguap, batang pengaduk, tabung reaksi, rak tabung reaksi, bunsen, kaki tiga, timbangan analitik (Sartorius), kertas saring, water bath, rotary evaporator (Ilettich), jangka sorong (Tricle brand), maserator (Canister), lemari pendingin (Electrolux), perforator (Ika), autoklav dan alat gelas lain yang biasa digunakan di labolatorium.

Bahan yang dibutuhkan pada penelitian ini adalah ammonia, kloroform, asam klorida $2 \mathrm{~N}$, pereaksi Mayer, Dragendroff, amilalkohol, serbuk magnesium, aquadest, etanol $70 \%$,DMSO, besi (III) klorida $1 \%$, gelatin, eter, larutan vanilin $10 \%, \mathrm{CH}_{3} \mathrm{COOH}$ glacial, $\mathrm{H}_{2} \mathrm{SO}_{4}$ pekat.

\section{Pengumpulan Tanaman}

Umbi bawang merah yang diperoleh dari pasar tradisional Ujung Berung Bandung, Jawa Barat. Bagian yang digunakan adalah bagian umbinya.

\section{Determinasi Tanaman}

Untuk kebenaran sampel, umbi bawang merah yang digunakan dilakukan determinasi di Laboratorium Biologi Universitas Padjadjaran, Jatinangor, Sumedang, Jawa Barat.

\section{Pembuatan Simplisia}

Bawang merah dikupas,dicuci bersih, dipotong kasar, kemudian dikeringkan di oven pada suhu tidak lebih dari $60^{\circ} \mathrm{C}$,selama 6-8 jam hingga bobot konstan, dan didapatkan kadar air dibawah 5\% (Departemen Kesehatan RI, 1985).

\section{Penentuan Kadar Air}

Alat moisture balance dipastikan pada posisi nol dan jarum menunjukkan posisi netral. Sebanyak 2 g simplisia bawang merah diletakkan merata di atas alumunium serta anak timbangan $2 \mathrm{~g}$ sehingga posisi jarum berada di tengah. Lampu dinyalakan dan suhu diatur pada $100^{\circ} \mathrm{C}$ sampai jarum merah bergerak ke arah kanan dan pengukuran dihentikan setelah jarum merah berhenti bergerak, kemudian lampu dipadamkan. Tombol pengukur diputar ke sebelah kiri sampai jarum kembali ke posisi semula, kadar air dibaca (DEPKES RI., 2000). 
Quagga: Jurnal Pendidikan dan Biologi

Volume 11, Nomor 2, Juli 2019

\section{Ekstraksi Tanaman Uji}

Diambil simplisia umbi bawang merah sebanyak 200 gram, dimaserasi dengan etanol 96\% sebanyak 2 liter selama 3 hari pada suhu ruangan dan terlindung dari sinar matahari langsung. Maserat yang diperoleh disaring bertahap. Penyaringan tahap 1 dilakukan dengan kapas, penyaringan tahap 2 dilakukan dengan menggunakan kertas saring (kertas wattman no 52), dan maserat ditampung dalam wadah tertutup. Proses maserasi dilakukan sampai warna maserat yang diperoleh jernih atau mendekati jernih. Maserat yang hasilkan akan dipekatkan dengan vacum rotary evaporator pada suhu $45^{\circ} \mathrm{C}$ hingga diperoleh ekstrak kental etanol 96\%. Ekstrak kental yang diperoleh dihitung beratnya dan dilakukan perhitungan rendemen.

$$
\text { Kadar Air }=\frac{\text { Bobot Awal }- \text { Bobot Akhir }}{\text { BobotAwal }} \times 100 \%
$$

\section{Karakterisasi Ekstrak}

Pemeriksaan Organoleptik Ekstrak

Pada ekstrak yang diperoleh dilakukan identifikasi secara organoleptis meliputi pemeriksaan bentuk, warna, bau dan rasa (DEPKES RI,2000).

\section{Uji Skrining Fitokimia}

Skrining fitokimia dilakukan terhadap simplisia untuk memeriksa adanya metabolit sekunder. Secara umum senyawa ini meliputi Alkaloid, Flavonoid, Saponin, dan Tanin. Identifikasi Polifenol dilakukan sebagai berikut:

Sebanyak $500 \mathrm{mg}$ sampel simplisia disari dengan $10 \mathrm{~mL}$ air suling, disaring kemudian filtratnya diencerkan dengan aquades sampai tidak berwarna. Diambil $2 \mathrm{~mL}$ larutan kemudian ditambahkan besi (III) klorida $1 \%$ dan gelatin. Hasil positif ditunjukkan dengan terjadi warna biru atau hijau kehitaman. Sampel ekstrak dan fraksi ditambahkan $1 \mathrm{~mL}$ aquadest, kemudian diperlakukan sama, mulai dari penambahan besi (III) klorida $1 \%$ (Departemen Kesehatan RI, 1985)

\section{Sterilisasi Alat}

Alat-alat yang akan disterilkan terlebih dahulu dicuci bersih dan dikeringkan. Cawan petri dibungkus dengan kertas perkamen untuk alat-alat gelas (tabung reaksi, gelas beker, erlenmeyer) ditutup mulutnya dengan kapas steril yang dibalut dengan kain kasa steril, kemudian dibungkus dengan kertas perkamen, disterilkan delam oven pada suhu $150^{\circ} \mathrm{C}$ selama 2 jam. Kasa, kapas, tali, gelas ukr, pipet tetes dan kaca
p-ISSN 1907-3089, e-ISSN2651-5869

https://journal.uniku.ac.id/index.php/quagga

objek juga di bungkus dengan kertas perkamen dan disterilkan dengan autoklaf pada suhu $121^{\circ} \mathrm{C}$ dengan tekanan $1 \mathrm{~atm}$ selama 15 menit. Untuk alat seperti ose, batang L (untuk metode spread plate) dan pinset disterilkan dengan metode Flamber, yakni direndam dengan alkohol $70 \%$ selama 5 menit kemudian pijijarkan dengan api bunsen. Alat yang berbahan karet seperti karet pipet, disterilkan dengan direndam dalam alkohol $70 \%$ selama 5 menit. Laminar air flow disterilkan dengan menyalakan lampu UV selama 2 jam, dibersihkan dari debu, disemprot dengan alkohol 70\% didiamkan selama 15 menit (Pratiwi, 2008)

\section{Peremajaan Bakteri}

\section{Pembuatan Media Agar Miring}

Sebanyak 8 gram Nutrient Agar disuspensikan dalam $400 \mathrm{~mL}$ aquades steril, kemudian dipanaskan hingga menididih. Dilakukan pengadukan dengan magnetic stiler untuk memastikan media telah tersuspensi secara sempurna. Media yang sudah tersuspensi sempurna, disterilkan dengan autoklaf pada suhu $121^{\circ} \mathrm{C}$ selama 15 menit (Pratiwi, 2008)

Media yang sudah steril, kemudian dituangkan ke tabung reaksi steril sebanyak $5 \mathrm{~mL}$ dalam kondisi hangat $\left(40^{\circ} \mathrm{C}-45^{\circ} \mathrm{C}\right)$. tabung reaksi yang berisi media, kemudian dimiringkan dengan kemiringan sekitar $30^{\circ}-45^{\circ}$. kemudian mulut tabung reaksi ditutup dengan kapas yang dibalut kain kasa steril. Selanjutnya diamkan sampai media memadat. Pembuatan media dilakukan secara aseptis dalam Laminar Air Flow (Hidayat, 1999)

\section{Proses Peremajaan Bakteri}

Bakteri uji ditumbuhkan pada media Nutrient Agar (NA) dengan cara menggoreskan bakteri dari biakan murni menggunakan jarum ose pada permukaan agar . Bakteri yang sudah digoreskan pada media selanjutnya diinkubasi pada suhu $37^{\circ} \mathrm{C}$ selama $2 \times 24$ jam (Benson, 2001). 
Quagga: Jurnal Pendidikan dan Biologi

Volume 11, Nomor 2, Juli 2019

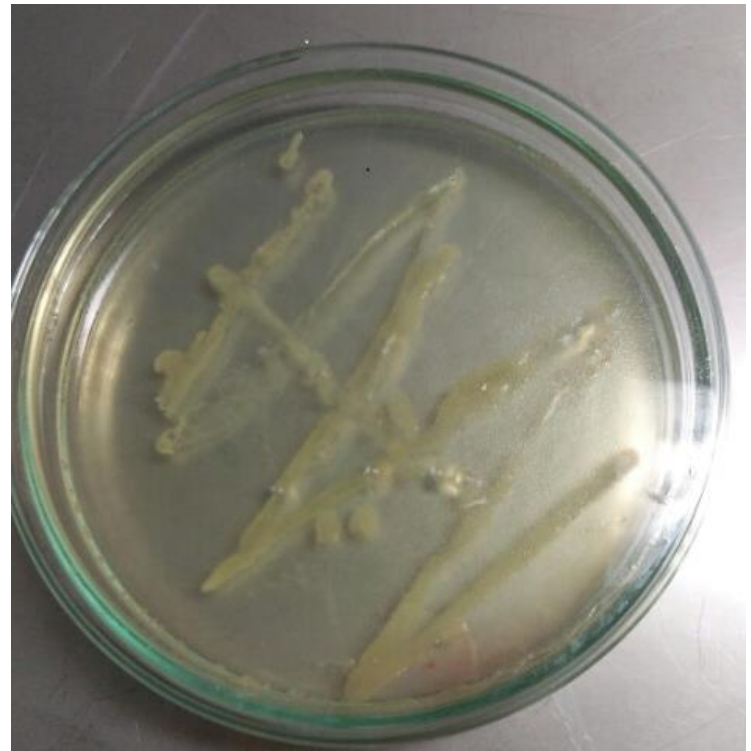

Gambar 1. Penumbuhan bakteri uji pada medium Nutrient Agar (NA)

\section{Pembuatan Suspensi Bakteri}

Sebanyak 2 ose bakteri uji hasil peremajaan, disuspensikan dalam $2 \mathrm{~mL} \mathrm{NaCl}$ fisiologis dalam tabung reaksi steril dan dihomogenkan dengan vortex selama 15 detik, kemudian kekeruhannya dilihat dengan membandingkan kekeruhan standar 0,5 Mc Farland (setara dengan $1,5 \times 10^{8}$ CFU/Ml)(Pratiwi,2008).

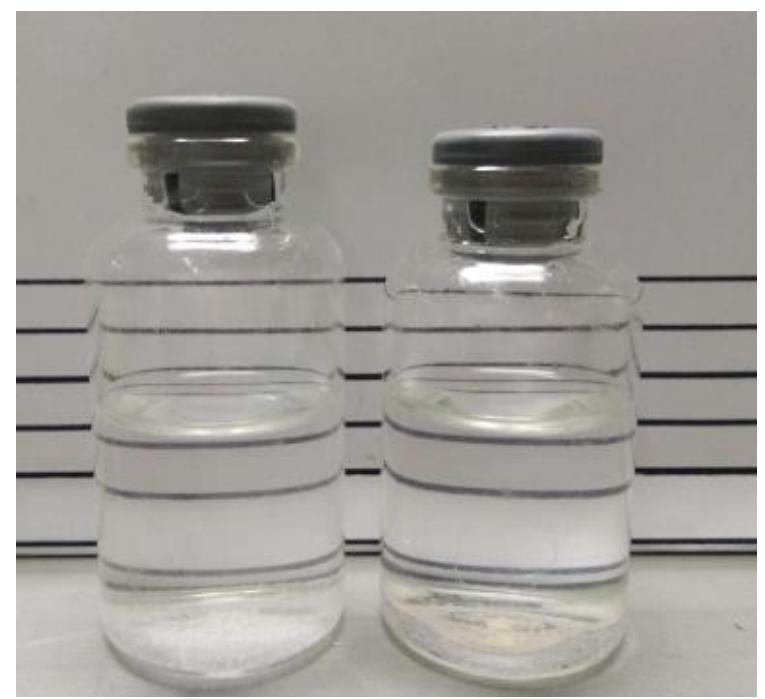

Gambar 2. Suspensi Bakteri

\section{Pembuatan Konsentrasi larutan Uji}

Pada pengujian aktivitas antibakteri ekstrak bawang merah, konsentrasi yang dibuat merujuk pada penelitian Hatijah (2013). Ekstrak dibuat larutan denganvariasi konsentrasi etanol 96\% menjadi beberapa seri konsentrasi, yaitu 5\%, $10 \%, 20 \%, 30 \%$ dan $40 \%$. Pada penelitian ini digunakan larutan DMSO sebagai pelarut.
p-ISSN 1907-3089, e-ISSN2651-5869

https://journal.uniku.ac.id/index.php/quagga

\section{Uji aktivitas anti bakteri}

Ekstrak ekstrak bawang merah diuji aktivitas bakterinya terhadap Salmonellatypi, dengan metoda difusi agar. Proses tersebut dilakukan untuk mengetahui pada konsentrasi berapa yang memberikan aktivitas anti bakteri terbesar.

Bakteri uji disuspensikan kedalam $\mathrm{NaCl}$ fisiologis, kemudian diinkubasi selama 18-24 jam pada suhu $37^{\circ} \mathrm{C}$. Kekeruhan suspense bakteri uji disesuaikan dengan kekeruhan larutan standar $0,5 \mathrm{Mc}$ Farland.

Dituangkan $20 \mathrm{~mL}$ agar nutrient bersuhu 40$45^{\circ} \mathrm{C}$. Campuran digoyangkan dan dibiarkan sampai memadat, lalu dioleskan suspensi bakteri dengan menggunakan rod stirer segitiga. Didiamkan 1 jam dibawah Laminar Air Flow (LAF).

Pada agar dibuat lubang-lubang menggunakan perforator. Kedalam lubang-lubang tersebut dimasukkan ekstrak bawang merah sebanyak 50uL dengan masing-masing konsentrasi. Cawan petri diinkubasi pada incubator selama 18-24 jam pada suhu $37^{\circ} \mathrm{C}$. Aktivitas anti bakteri yang ditujukan dengan pembentukan daerah bening di sekeliling lubang, diukur menggunakan jangka sorong.

\section{Ulangan Rumus Gomez}

Penelitian ini menggunakan rancangan acak lengkap (RAL). Jumlah pengulangan berdasarkan rumus:

$$
\begin{gathered}
(t)(r-1) \geq 20 \\
6(r-1) \geq 20 \\
6 r-6 \geq 20 \\
6 r \geq 20+6 \\
r \geq 26 / 6 \\
r \geq 4,33 \\
r \geq 4
\end{gathered}
$$

\section{keterangan :}

$\mathbf{t}=$ jumlah perlakuan

$\mathbf{r}=$ jumlah pengulangan

20 derajat bebas untuk RAL

\section{Analisis Data}

Untuk menganalisis data pada penelitian kali ini akan menggunakan analisis ANOVA (Analisys of Variances) one way.

\section{HASIL DAN PEMBAHASAN \\ Hasil Penetapan Kadar Air Simplisia}

Tujuan penetapan kadar air adalah untuk mengukur kandungan air yang terdapat dalam simplisia, serta memberikan batasan minimal rentang tentang besarnya kandungan air dalam bahan. Kadar air dari simplisia bawang merah 
Quagga: Jurnal Pendidikan dan Biologi

Volume 11, Nomor 2, Juli 2019

adalah 2\%, halini telah memenuhi syarat kadar air yang telah ditetapkan bahwa kadar air dibawah 5\% (DEPKES, 2000).

\section{Hasil Ekstraksi}

Sebanyak 200 g simplisia diekstraksi dengan cara maserasi sehingga diperoleh ekstrak kental umbibawang merah (Allium cepa L.) sebanyak $89 \mathrm{~g}$ dengan rendemen sebesar $44,5 \%$.

\section{Karakterisasi Ekstrak}

Pemeriksaan Organoleptik Ekstrak

Pada ekstrak yang diperoleh dilakukan identifikasi secara organoleptis meliputi pemeriksaan bentuk, warna,bau dan rasa.

Tabel 1. Pemeriksaan Organoleptik Ekstrak Umbi Bawang Merah (Allium cepa L.)

\begin{tabular}{cc}
\hline Pengamatan & Hasil \\
\hline Rasa & Sedikitasin \\
Bau & Khas bawang merah \\
Warna & Coklat tua \\
Tekstur & Kental \\
\hline
\end{tabular}

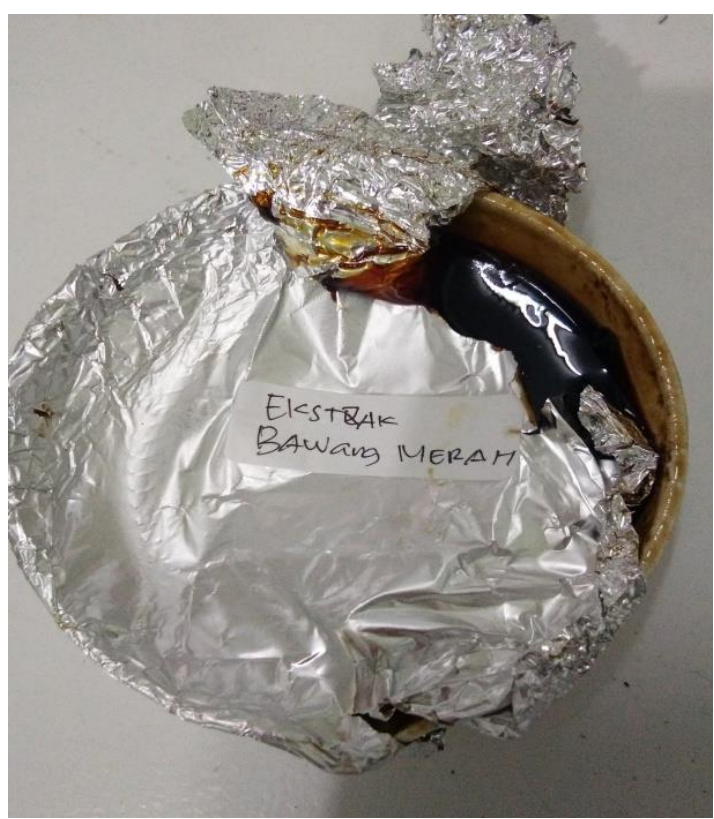

Gambar 3. Ekstrak Bawang Merah

\section{Hasil Skrining Fitokimia}

Etanol digunakan sebagai pelarut karena etanol merupakan pelarut universal sehingga mampu menarik sebagian besar senyawa yang terkandung dalam simplisia. Hasil skrining fitokimia dapat dilihat pada Tabel 2.
p-ISSN 1907-3089, e-ISSN2651-5869

https://journal.uniku.ac.id/index.php/quagga

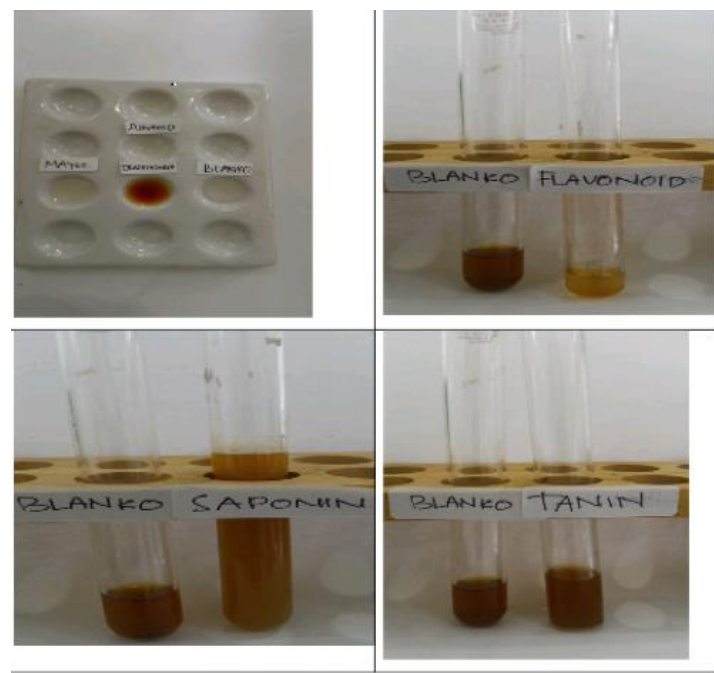

Gambar 4. Hasil Skrining Fitokimia

Berdasarkan hasil skrining fitokimia simplisia dari ekstrak umbi bawang merah (Allium cepa L.) mengandung beberapa metabolit sekunder yang tidak rusak selama proses ekstraksi.

Tabel 2. Skrining Fitokimia ekstrak bawang merah (Allium cepa L.)

\begin{tabular}{ccc}
\hline Metabolit & $\begin{array}{c}\text { Simplisia } \\
\text { kasar }\end{array}$ & Ekstrak \\
Sekunder & + & + \\
Alkaloid & + & + \\
Flavonoid & - & - \\
Tanin & - & + \\
Saponin & + & + \\
Polifenol & +
\end{tabular}

Keterangan :

$+:$ terdeteksi

- : tidak terdeteksi

\section{Pembuatan Konsentrasi larutan Uji}

Ekstrak dibuat larutan denganvariasi konsentrasi etanol $96 \%$ menjadi beberapa seri konsentrasi, yaitu 5\%, 10\%, 20\%, 30\% dan 40\%. Pelarut yang digunakan pada penelitian ini yaitu larutan DMSO sebagai, didapatkan hasil pada Tabel 3.

Tabel 3. Pembuatan Konsentrasi larutan Uji

\begin{tabular}{cccc}
\hline \multirow{2}{*}{ NO } & \multirow{2}{*}{ Konsentrasi } & \multicolumn{2}{c}{ Hasil perhitungan } \\
\cline { 3 - 4 } & & Ekstrak & DMSO \\
\hline 1 & $5 \%$ & $0,25 \mathrm{~g}$ & $5 \mathrm{~mL}$ \\
2 & $10 \%$ & $0,5 \mathrm{~g}$ & $5 \mathrm{~mL}$ \\
3 & $20 \%$ & $1 \mathrm{~g}$ & $5 \mathrm{~mL}$ \\
4 & $30 \%$ & $1,5 \mathrm{~g}$ & $5 \mathrm{~mL}$ \\
5 & $40 \%$ & $2 \mathrm{~g}$ & $5 \mathrm{~mL}$ \\
\hline
\end{tabular}

Hasil yang didapat kemudian dimasukan pada wadah vial yang sudah disterilkan, Kemudian konsentrasi larutan uji ini disimpan pada 
Quagga: Jurnal Pendidikan dan Biologi

Volume 11, Nomor 2, Juli 2019

Laminar Air Flow agar menjaga kestbilannya pada saat pengujian pada bakteri S.typhi.

Uji aktivitas anti bakteri

Hasil Pengukuran dapat dilihat pada Tabel 4.

Tabel 4. Uji Aktivitas Bakteri

\begin{tabular}{cccccc}
\hline Jml & \multicolumn{5}{c}{ Hasil Skala $0,05 \mathrm{~mm}$} \\
\cline { 2 - 6 } Uji & $5 \%$ & $10 \%$ & $20 \%$ & $30 \%$ & $40 \%$ \\
\hline 1 & 11.10 & 16.20 & 19.20 & 22.75 & 26.20 \\
2 & 11.15 & 16.35 & 19.15 & 22.70 & 26.10 \\
3 & 11.25 & 16.30 & 19.25 & 22.80 & 26.15 \\
4 & 11.35 & 16.25 & 19.45 & 22.75 & 25.45 \\
\hline
\end{tabular}

\section{Analisis Data}

Untuk menganalisis data pada penelitian kali ini akan menggunakan analisis ANOVA (Analisys of Variances) one way.

ANOVA
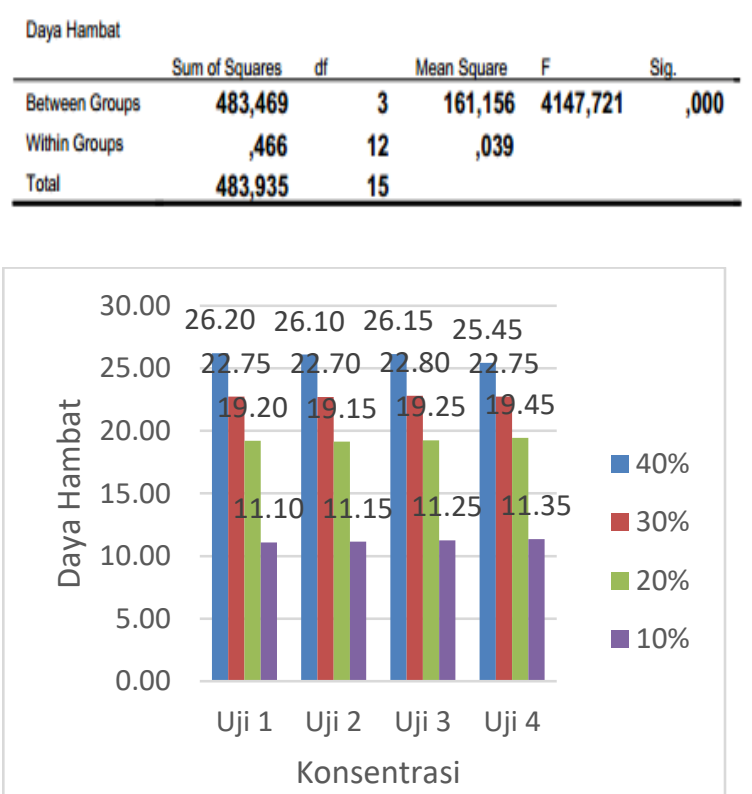

Gambar 5. Hasil PengukuranUji aktivitas anti bakteri pada berbagai konsentrasi

Karena nilai signifikan yang didapat $<0,05$, maka data yang dapat signifikan hal ini menunjukkan semua data berbeda. Jadi data di atas dapat diterima.

Hasil optimum pengujian ekstrak pada bakteri Salmonella typhi No. ATCC 19430 terdapat pada konsentrasi $40 \%$ hal ini menunjukan semakin besar ekstrak berbanding lurus dengan besaran daya hambat.
p-ISSN 1907-3089, e-ISSN2651-5869

https://journal.uniku.ac.id/index.php/quagga

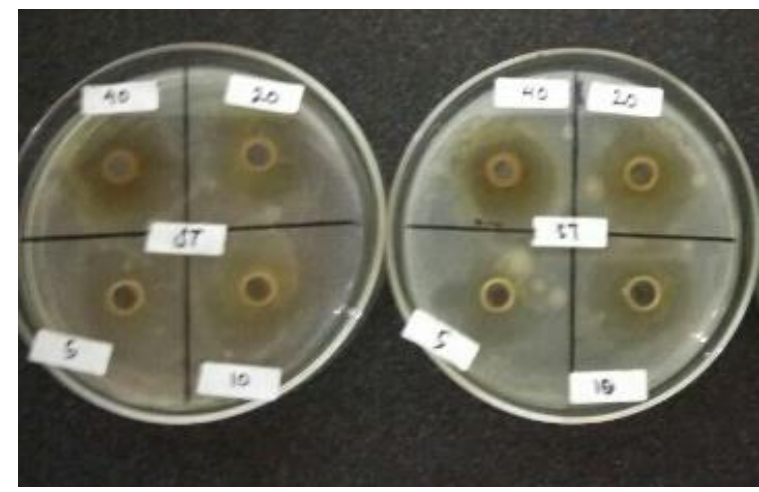

Gambar 6. Hasil Uji Ekstrak Bawang Merah Pada Aktivitas Bakteri Salmonella typhi

\section{SIMPULAN}

\section{Simpulan}

Berdasarkan penelitian yang telah dilakukan dapat disimpulkan : Hasil optimum pengujian ekstrak Bawang Merah (Allium cepa L.) pengaruhnya terhadap bakteri Salmonella typhy No. ATCC 19430 terdapat pada konsentrasi $40 \%$. Hal ini menunjukkan semakin besar konsentrasi eksrtrak, semakin besar daya hambat yang dihasilkan.

\section{Saran}

Perlu adanya penelitian lebih lanjut dari aktivitas daya hambat ekstrak Bawang Merah (Allium cepa L.) terhadap Salmonela thypi secava in vivo.

Perlu dilakukan penelitian lebih lanjut terhadap sifat toksisitas bawang merah khususnya pada pasien yang terpapar Salmonella typhi.

Perlu dilakukan penelitian lebih lanjut terhadap cara ekstraksi bawang merah yang lebih efektif.

\section{REFERENSI}

Anonim, 1985, Materia Medika Indonesia, Jilid IV, Departemen Kesehatan RI, Jakarta, p.15-19.

Anonim, 2000, Parameter Standar Umum Ekstrak Tumbuhan Obat, 3-5,DEPKES RI,Jakarta.

Benson, 2001, Microbiological application laboratory manual in general microbiology 8th ed, The Mc Graw-Hill Companies, New York: xi 478 hml.

Cliver, 1990. Salmonella, In: Foodborne Disease D.O. Cliver (ed), Academic Press. Inc., 185-204. 
Quagga: Jurnal Pendidikan dan Biologi

Volume 11, Nomor 2, Juli 2019
p-ISSN 1907-3089, e-ISSN2651-5869

https://journal.uniku.ac.id/index.php/quagga

Hatijah, St., Husain, D.R ., dan Sartini., 2013, Jurnal Bioaktivitas Minyak Atsiri Umbi Lapis Bawang Merah Allium cepa L. localasal Bima terhadap Bakteri Streptococcus mutans penyebab kariesgigi.

Hidayat, Yusuf dan Sutarma.1999. Teknik Pembuatan Kultur Media Bakteri. Balai Penelitian Veteriner. Bogor.

KG Wiryawan, 2005, Jurnal tentang anti bakteri dari Temulawak,Jahe, dan Bawang Putih Terhadap Salmonella typhimurium

Lud W, 2004. Mikrobiologi Umum. UMM Press Malang

Pratiwi, S.T., 2008, Mikrobiologi Farmasi Jakarta, Penerbit Airlangga.

Stecher P.G., (Editor), 1968, The Merck Index: an Encyclopedia of Chemicals and Drugs, Merck \& Co. Inc. USA., p. 31-32 